\title{
Shennan Road and the Modernization of Shenzhen Architecture
}

\section{Cong Sun, Charlie Q. L. Xue, and Lujia Zhang}

City University of Hong Kong, Department of Architecture and Civil Engineering, Hong Kong

\section{Abstract}

Shenzhen sets an example for rapid development of urban planning and construction. It was the starting point of the most massive city-construction movement in contemporary China. In less than 40 years, many representative urban space and buildings on the main east-west highway--Shennan Road, have witnessed the formation of the banded multi-center structural layout and the miraculous expansion of the city. Many of those iconic buildings are designed by Hong Kong or foreign architects. With the continuous development of the length and width of Shennan road, its broad and prosperous image is not only a symbol of the fruits of reform and opening up in Shenzhen or even China, but also contains the growth history of Shenzhen's architectural modernization. This paper reviews and summarizes the changes of the urban fabric and the design

Corresponding Author: Cong Sun cong.sun@my.cityu.edu.hk

Received: 15 March 2019 Accepted: 25 May 2019 Published: 20 November 2019

Publishing services provided by Knowledge

(c) Cong Sun et al. This article is distributed under the terms of the Creative Commons.

Attribution License, which permits unrestricted use and redistribution provided that the original author and source are credited.

Selection and Peer-review under the responsibility of the Architecture across Boundaries Conference Committee.

\section{G OPEN ACCESS} trend of representative buildings along with the Shennan Road in different periods by the historical research methods. Combined with the transfer path of the city center, this study analyzes what kind of unique role the street and buildings act as in the development of urban structure in Shenzhen, and expound what other urban functions and symbolic meaning they have. In the context of globalization, this article discusses how do the buildings designed by foreign architects change our city, the driven factors behind the phenomenon of the design trend change. This research can make a supplement to the history and theory of the modernization of contemporary Chinese architecture.

Keywords: Shenzhen Architecture, Shennan Road, Modernization, Design Trend, Cross-border Practice, Rapid Urbanization

\section{Introduction}

The 30 years of China's architectural modernization is a process of continuously learning, drawing lessons from, transforming and absorbing contemporary Western architectural ideas and methods. The projects designed by foreign architects in China most directly influence the trend of Chinese architectural practice and theory.[1] Zou discussed about the impact of foreign architects' practice projects in China during 1980s on Chinese architecture. At that time, the types of projects designed by foreign architects were mostly hotels, and most of the foreign architects were not famous.[2] 
Xue divided the history of overseas architectural design in China into three stages and found out that in the early stage of reform and opening up, Hong Kong architects became a pioneer in entering mainland China. Until the 21st century, hotels and highend office buildings were the dominant building types among the works designed by overseas architects.[3] Benefiting from the location advantage and the setting of the reform and opening window, Shenzhen played in China's modernization process was quite apparent.[4]

In less than 40 years, Shenzhen has grown from a small town to a metropolis with the area, resident population, and GDP have increased by more than 7 times, 40 times and 8800 times, respectively. [5] This rapid growth is embedded in the construction history of the urban space, and the representative buildings. "Three paths and One Leveling," the slogan that inaugurated the construction of the Shenzhen Special Economic Zone(SEZ), three east-west avenues form the basis of all future urban incarnations.[6] Shennan Road is undoubtedly the most important one, many representative urban space and buildings on this trunk road, have witnessed the formation of the banded multi-center structural layout and the miraculous expansion of the city. In combination with the understanding of modernization in Chinese architecture in different periods, Yu discussed how a set of architectural language at that time influenced the architectural form of Chang'an Street in Beijing. In addition, Chang'an Street has connected a series of government buildings and representative projects with political significance. Afterward, other Chinese cities have followed Beijing and developed such major streets.[7] Just like Chang'an Street in Beijing, Shennan road running through the main area of Shenzhen is not only a symbol of the fruits of reform and opening up in Shenzhen or even China, but also contains the growth history of Shenzhen's architectural modernization.

Xiao and Yin analyzed the influential factors of the creation of Shenzhen iconic buildings in the early stage of reform and opening up, pointing out the enlightenment effect of the early Lingnan school architect on Shenzhen's architectural modernization. [8] From the 1990s, foreign architects began to appear enthusiastically, and their works gradually occupied an important position, and the building types were mainly office and commercial building.[9] From the second half of 1990s to the beginning of the 21st century, Shenzhen began to organize international competitions, which were mainly carried out around Futian Central District which located on both sides of Shennan Road.[10, 11] Short pointed out that organizing large events and spectaculars in particular cities is the most important way to construct and maintain globalization and modernity.[12] The Universiade held in 2011 set off a new round of construction boom, and it also pushed Shenzhen's infrastructure construction (mainly the metro system) to a climax. In June of 
the same year, the 178-kilometer metro line speared through the region like veins. Line 1 which almost coincides with Shennan Road extended from Overseas Chinese Town Area $(\mathrm{OCT})$ to the Baoan District where the airport is located. Shenzhen's construction center of gravity continued to move west.

Scholars in Shenzhen have accumulated some studies on the city, but mostly in the Chinese language, and it is difficult to be accessible for the overseas peers. From 1979 to 2018, almost 90 buildings designed by foreign architects were built in Shenzhen. More than half of them are located along Shennan Road. Through case studies of main areas and representative buildings built along the Shennan Road in different period, this paper penetrates the phenomenon of the "rapid urbanization", discovers the history and effects of governance preferences, international capital flow and foreign architects' intentions on the modernization of Shenzhen architecture. Buildings of various types are discussed in the framework of urban context, design trend and historical background. With the continuous expansion of the length and width of Shennan road, its broad and prosperous image has become a great symbol of China's socialist road and has obvious political significance. Meanwhile, the rapid growth of foreign architects' works also epitomizes the ambition and strong implementation of Chinese governments in the wave of urbanization and globalization.

\section{Three Stages of Urban Development}

\subsection{The initial stage-(1979-1989)}

In the preliminary stage of SEZ, the construction of infrastructure and cultural facility in Shenzhen was basically zero. Before the 1980s, the main road in Shenzhen Town was only 107 National Road, and Wenjindu was the end. Besides, a People's Cinema was set up in 1949, the Shenzhen Theater opened in 1958, the exhibition hall in 1975, and together these had cost 600,000 yuan and they served an area of 2,751 square kilometers.[13] In 1980, the Shenzhen Special Economic Zone was established. Due to the narrow terrain, the construction of a "decent road" of east-west direction quickly became the consensus of the decision-makers. At the same year, a 2.1-kilometerlong and 7-meter-wide "gravel stone path" was built from Luohu group to Shangbu Group, this is called Shennan Road. In 1981, the new mayor who had just returned from the inspection in Singapore decided to extend the road to 100 meters wide and was immediately opposed by various people. [14] At the beginning of 1987, this road has become a 6.8-kilometer-long, 21-meter-wide traverses the downtown area of Shenzhen 
at that time. Buildings on both sides of the road were gradually starting to increase. The layout of the first-generation skyscrapers has formed the main axis of the city. (Fig. 1) Before the 1990s, looking at the whole of China, a cluster of skyscrapers developed in accordance with the overall plan only existed in Luohu District of Shenzhen.

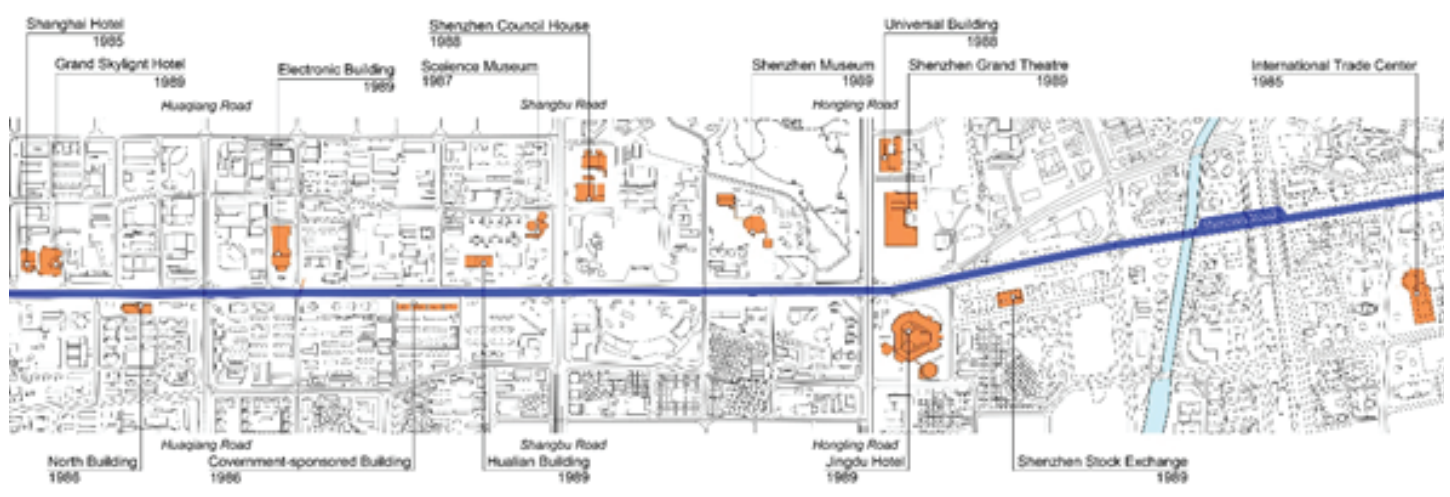

Figure 1: Newly built buildings along Shennan Road completed in 1979-1989. Drawn by Sun Cong.

Most of the buildings are functionalism modern architecture styles with minimalism facades. For commercial or office building, the architectural shape are mostly square boxes with simple horizontal/vertical strip windows or brown glass curtain wall with dark brown aluminum window frame in facades, and the architectural image is tough and solemn. For cultural buildings, four of the eight projects were designed by Lingnan School architects, they are: Shenzhen library, Shenzhen Museum, Shenzhen Grand Theatre, Science Museum. In the 1950s and 1970s, the "Lingnan School of modern architecture", centered on Guangzhou, played an active role in the construction of Shenzhen at the beginning of reform and opening-up.[15] In the early 1980s, "Lingnan" is a fortress of Chinese modern architecture, which was admired in architectural design circle. It is worth mentioning at that time almost no foreign architects participated in the design.

\subsection{The growth/expansion stage-(1989-1996)}

In 1992, China's patriarch Deng Xiaoping delivered the renowned "South Tour Speeches" when inspecting coastal areas in Guangdong province. Under the slogan of "Development is the top priority," a new round of construction started, and the deadlock of Reform and Opening Up was broken. Shenzhen's development in this stage embodied the further realization of the new groups' construction and urban expansion.[16] In 1994, the 25.6-kilometer-long and 135-meter-wide avenue was completed. Dozens of skyscrapers and various large-scale commercial and cultural buildings have made the facades and spatial patterns on both sides generally determined. The main battlefields 
are concentrated in the Caiwuwei Financial Center and the Overseas Chinese Town Area (OCT). With the introduction of overseas capital, foreign architects (including HK, Macao and Taiwan) began to get involved in landmark projects, mainly are ethnic Chinese and Hong Kong architects.

In 1995, the Diwang Building was born at Caiwuwei Financial Center. It replaced the Guomao Building, which is famous for its "three days, one floor" speed, and became the tallest building in Shenzhen and even Asia. Meanwhile, it is the representative of the second generation of skyscrapers in Mainland China. In addition to creating a record of height, the American Chinese architect K.Y. Cheung also created a record of slim volume, the width and height ratio reached 1:7. In China's conventional regulation, the building width and height ratio should not be over 1:5, otherwise it will deflect. Architects and structural engineers from the US and Japan well solved the problem by consolidating the stiffness of the structure. It is China's first super high-rise building with frame steel structure. At this time, in the eastern part of Shennan Road, there was almost no vacant plot along the street. However, the colours and shapes of the different skyscrapers were too bright and gave an uncoordinated effect.

On the other side, based on Singapore planner Meng Ta Cheang's master plan, the success of a theme park named Splendid China not only created a new style of Chinese theme park but also brought huge benefits to the OCT Group, thus promoting the development of other projects in the $\mathrm{OCT}$, and many large construction projects-Huaxia Art Center and the Folk Culture Village, He Xiangning Art Museum were launched simultaneously. Huaxia Art Center was designed by Huasen Architectural \& Engineering Designing Consultants Ltd. (HSArchitects) (a design firm established in 1980 as China's first Sino-foreign joint venture, founded by the Architecture Design Institute of the Ministry of Construction and Hong Kong Senyang International Co., Ltd.). HSArchitects gained a huge reputation by designing Nan Hai Hotel and Shenzhen Gymnasium. HSArchitects continued to create a group of architectural designs in the OCT, including almost 30 high-rise residential buildings and other noteworthy public buildings, which virtually cornered the market. In the initial stage of modernization practice in the Reform and Opening Up from the 1980s to the 1990s, an eclecticism appeared in architectural design, namely, the combination and coexistence of traditional Chinese culture and Western form.[17] Huaxia Art Center was a typical example. The architect combined traditional cultural elements with the function and techniques of modern architecture. First, in terms of the materials selected, traditional pink concave-convex bricks were used, with gray bricks in the interlayer forming a horizontal line segmentation. Second, for the façade detail design, red sandstone relief was used in the stairs at the western 
side and external wall above the water pool at the southeast side, which represented ancient China's traditional philosophy. Third, for the landscape design, a Chinese-style garden was set up at both sides of the main entrance along the street in front.

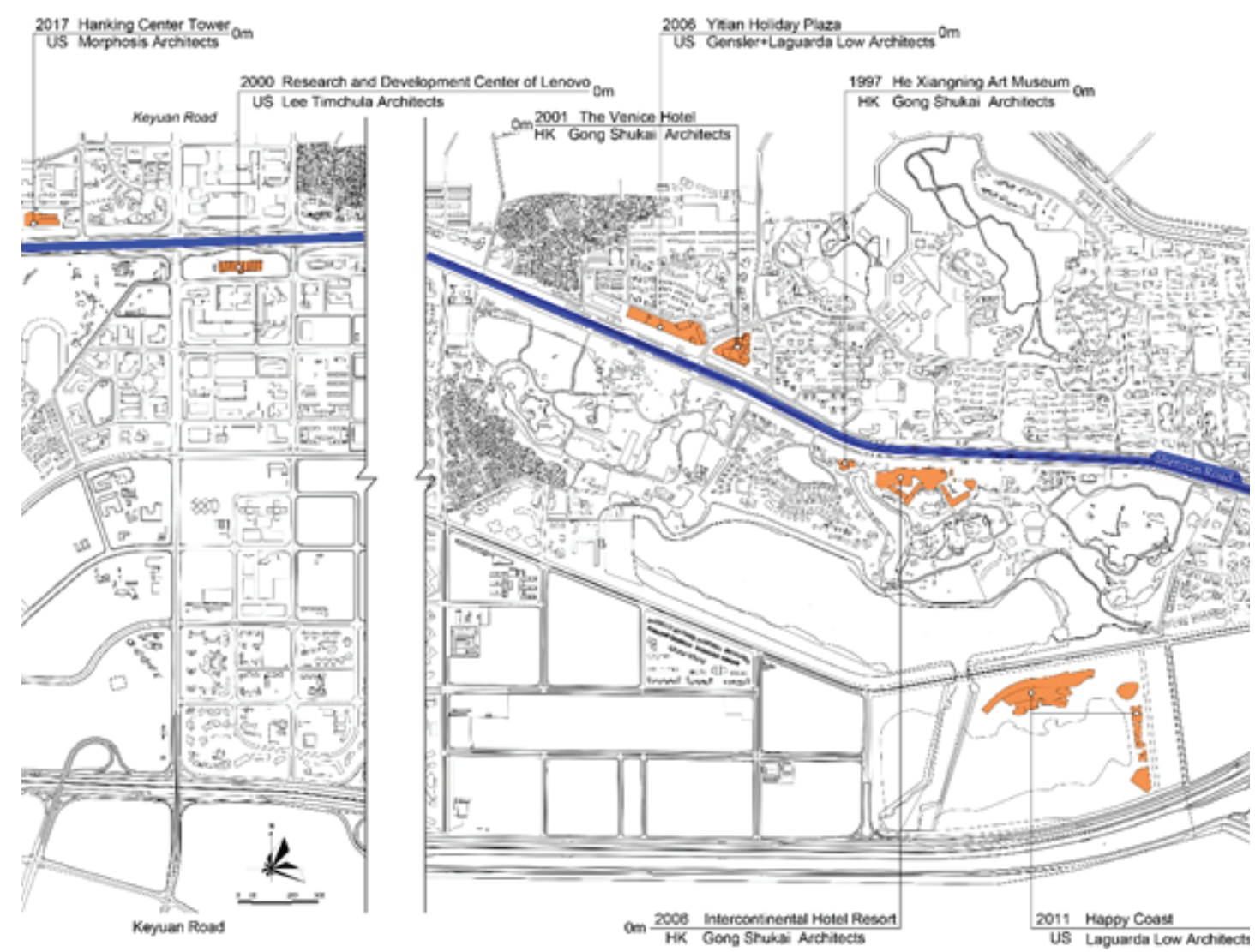

Figure 2: Nanshan District--Buildings which designed by foreign architect along Shennan Road completed in 1979-2018. Drawn by Sun Cong.

At this stage, foreign architects are largely accompanied by foreign capital, and mainly of them invited by foreign capital. At the beginning of the establishment of the SEZ, Hong Kong businessmen were the first group of "foreign capital". In the course of more than 20 years of economic development, Hong Kong capital has always been the "main force" of Shenzhen's foreign investment. On the other hand, with the advantages of geographical proximity and same language, it is not difficult to explain why Hong Kong and ethnic Chinese architects were more popular at that time. The active architects and design institutions include Sherman Kung, Ho \& Partners Architects, Liang Zhaoru Architects, etc. Hong Kong architect Sherman Kung was very active in the construction of OCT. The He Xiangning Art Museum was designed by him. Kung worked for Richard Meier in New York for 9 years, and uses the method similar to Richard Meier. These representative Hong Kong architects and design institutions have shown certain advancement in structural technology and architectural design. 


\subsection{The global stage-1997-2019}

Shenzhen entered the second pioneering stage in 1996. The government took Futian Central District as a key construction base. From 1997 to 1998 the Shenzhen Municipal Party Committee and Shenzhen Government initiated the bidding for designs of the six main infrastructures in Futian Central District and conceived a detailed planning scheme for the city's central axis. [18] Around 2004, with the opening of the subway, the city center gradually moved westward. The Futian Central District, which spans the north and south of Shennan Road, is the most intensive area for the government to invest in public buildings and commercial groups. From the planning to landmark buildings, more than half of them are designed by foreign architects, including many star architects all over the world. In the following ten years, along with the maturity of Futian Central District and the promotion of some urban renewal projects such as Huaqiangbei and Caiwuwei, the two sides of Shennan Road have become the main battlefields of European and American architects with totally more than 39 foreign designers' works rising from the ground.

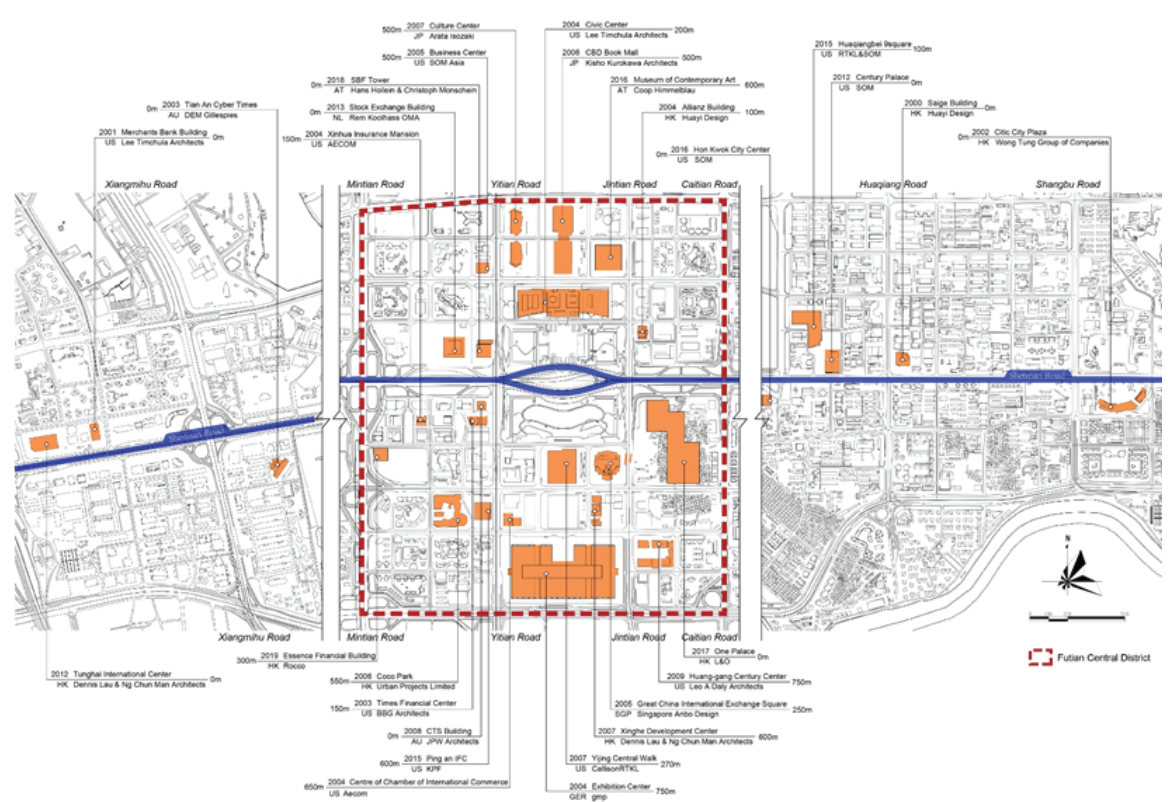

Figure 3: Futian District--Buildings which were designed by foreign architect along Shennan Road completed in 1979-2019. Drawn by Sun Cong

The Futian Central District competition was the starting point of international competition among CBDs, and influenced other cities in China, which reflects the general planning model of Chinese new towns. In this planning model, the cultural buildings cluster should be built near the administration center and the layout should be designed with orderly aesthetics. Besides, the planners attempt to create a political and cultural center under the axis control, so the design of cultural buildings should first meet political 
tastes. This urban aesthetic is rooted in China's traditional need for political power. The planning of Shenzhen Futian Central District adopted the Chinese traditional layout of a central axis, which stretched $2 \mathrm{~km}$ from the Lianhua Mountain in the north, crossing the Citizen Square to the Exhibition Center in the south. The public cultural facilities are mainly located along both sides of the north central axis. It is worth mentioning that the central axis system was designed and deepened in 1997 by Kurokawa Kisho, a Japanese modernist master. The north central axis stretches from the southern foot of Lianhua Mountain and the rooftop platform of Shenzhen's Central Book City to the platform of the Citizen Center. This is a typical "space on the drawing" pattern. The axis is not visible from eye-level and pedestrians on the road are unable to see the continuing route that was carefully designed by the planners. The concept of this central axis (ecological corridor) also attracts numerous new towns/districts in China to copy it.

Of course, there are still many amazing projects here. For example, the cultural center designed by Arata Isozaki. This was the first project that he won through fair competition in China, and thus opened up Chinese design market for him. The gorgeous harp-type curtain wall design not only constitutes a good-looking façade, but also introduces sunlight and outdoor scenery to interior. The other striking idea in Arata Isozaki's design is the "Golden Glass Tree" entrance hall, which is a brilliant space containing five golden pillars that support the polyhedral glass roof. After a decade of construction, compared with the budget cost in the requirement, the Cultural Center overspent 1 billion yuan. Since the application of steel structures was at a very preliminary stage in China 20 years ago, the steel structure for the golden tree was still an experimental construction. The construction team cooperated with Japanese structural engineers to make models, and then confirmed every joint on site, so it took a long time to construct. Another project is the urban design of the Southern part of the Central District (Thirteen Sister Building) is hosted by SOM. It is like Manhattan. Although there are many skyscrapers, the streets are small and dense, and walking on the street may suddenly meet a Street Park, making people feel relaxed.

\section{Conclusion}

Hong Kong, one of the miracles in east Asia, from its opening in 1841 to 2011, its population increased from 12,000 to 7.1 million. The population increased by 500 times in 70 years, and the same 500 times took Shenzhen only 30 years. So, the planning and construction system and the phenomenal expansion of Shenzhen have served as a template for rapid urbanization. In the context of rapid urbanization in 
Shenzhen, excessive input of landmark buildings over the past 30 years is the most striking architectural phenomenon in its massive upsurge of urban construction.

In 1980, a 2.1-kilometer-long and 7-meter-wide "gravel stone path" was born, bringing the construction out of the Luohu cluster. At the beginning of 1987, this road has become a 6.8-kilometer-long, 21-meter-wide traverses the downtown area of Shenzhen at that time. Most of the buildings on both sides are functionalism modern architecture styles with minimalism facades. The layout of the first-generation skyscrapers has formed the main axis of the city. In 1994, the 25.6-kilometer-long and 135-meter-wide avenue was completed. Dozens of skyscrapers and various large-scale commercial and cultural buildings have made the facades and spatial patterns on both sides generally determined. At this time, Shennan Road was no longer a common municipal road, but a new business card representing the impact of the urbanization campaign in China. With the introduction of overseas capital, foreign architects (including HK, Macao and Taiwan) began to get involved in landmark projects, mainly are ethnic Chinese and Hong Kong architects. Around 2004, with the opening of the subway, the city center gradually moved westward. The Futian Central District, which spans the north and south of Shennan Road, is the most intensive area for the government to invest in public buildings and commercial groups. From the planning to landmark buildings, more than half of them are designed by foreign architects, including many star architects all over the world. Overall, even with large and small regrets, Shenzhen is still a place full of planned and architectural ideals.

From 1979 to 2018, almost 90 buildings designed by foreign architects were built in Shenzhen. 46 of them are located along Shennan Road, more than a half. Take the completed works of foreign architects on both sides of Shennan Road as an example (limited to a radius of $\mathbf{8 0 0}$ meters from the centerline of the road), American architect account for $41 \%$ of the total, followed by Hong Kong and European architects, accounting for $35 \%$ and $13 \%$ respectively.

American architects have played an extremely important role in this process, far more than the work of designers from Europe and other Asian countries during the same period. Because the image of the American metropolis and the work of American designers are in line with the Chinese city's imagination of modernization. Besides, Hong Kong businessmen have been the main force in the economic development of SEZ, especially the industrial development. Hong Kong businessmen brought not only capital but also advanced ideas. The enlightenment of Hong Kong architects and Hong Kong developers on the architectural design of the SEZ in early stage was crucial. Foreign architects designed large commercial and office buildings for cities, accounting for $54 \%$, 


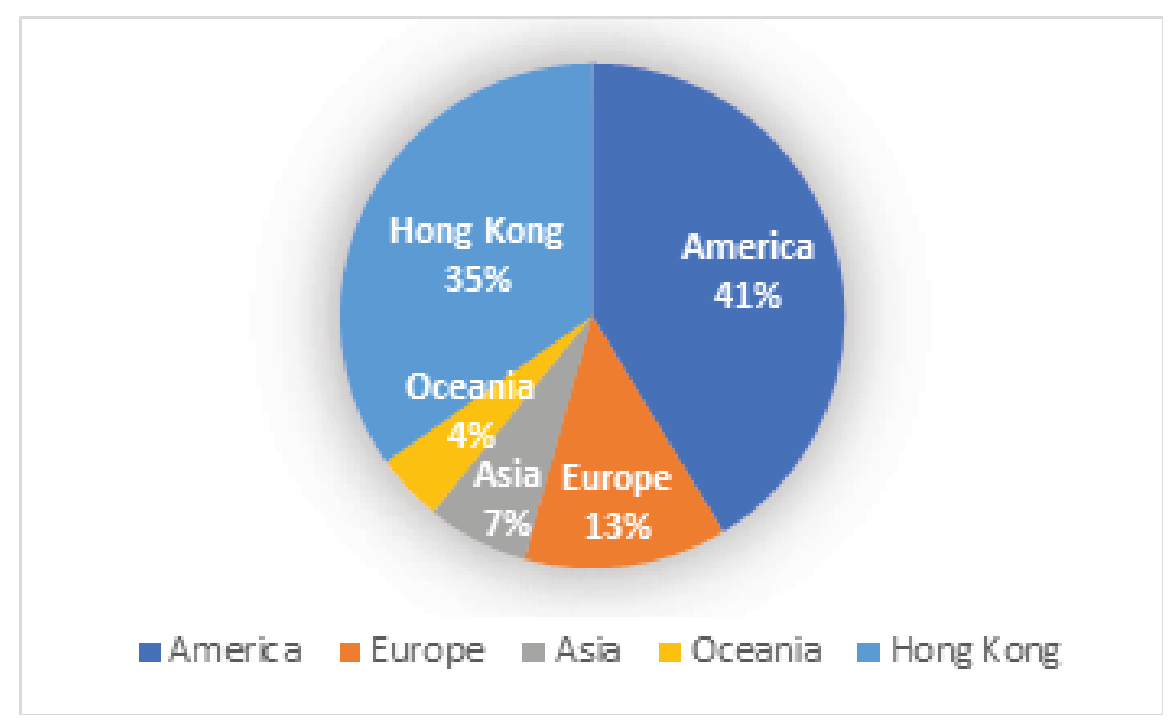

Figure 4: Comparison of total number of architect projects come from different regions

followed by retail buildings accounting for $18 \%$, and cultural buildings accounting for $11 \%$ respectively.

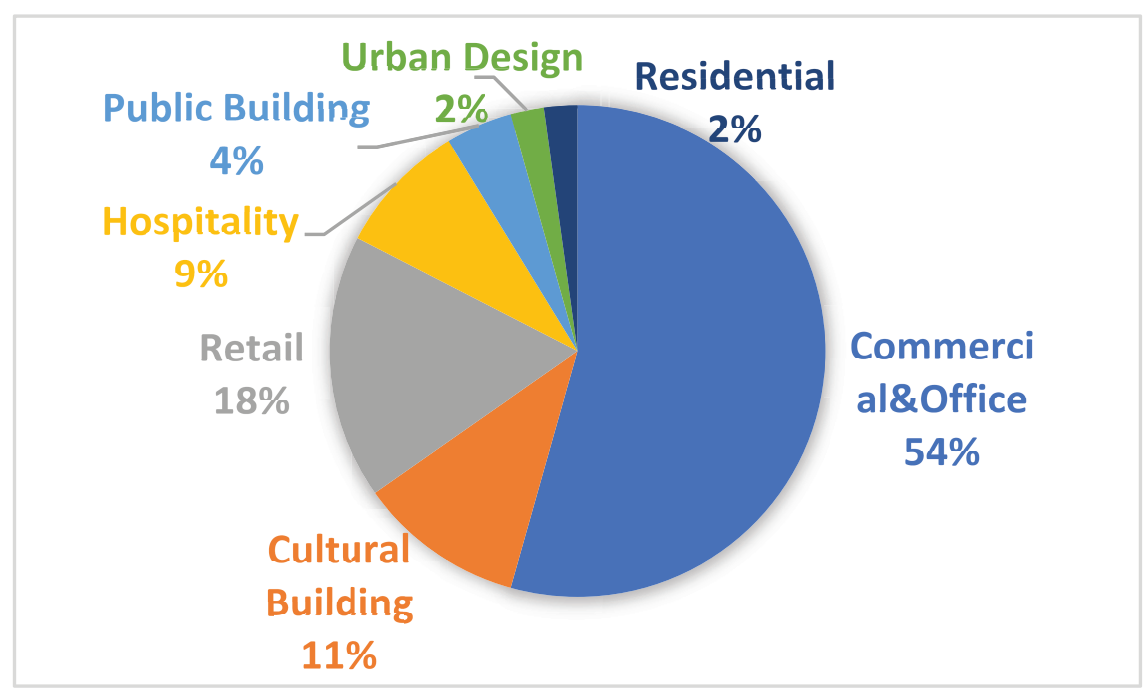

Figure 5: Comparison of different types of projects.

Commercial and office buildings are mostly landmark buildings in cities. Developers or decision-makers want overseas designers to bring new ideas or most advanced technologies. Skyscrapers along Shennan Road are rather outcomes of business capital speculations, they are the powerful signs to show Shenzhen's ambition to participate the global rank. The use of international architects and most fabulous design skills are indispensable for such an aspiration. 


\section{Funding}

This paper is part of a study supported by the City University of Hong Kong, Project No. 7005135; and Research Grant Council, Hong Kong Government, No.CityU.11658816.

\section{Acknowledgement}

My greatest gratitude goes to my respected supervisor, Professor Charlie Q.L. Xue, both for his ongoing support, helpful advice and warm encouragements during the process of writing the manuscript.

\section{Conflict of Interest}

The authors have no conflict of interest to declare.

\section{References}

[1] Zhu, Y. M. (2018). From Xiangshan hotel to CCTV: a dialogue between Chinese and western architecture and the crisis of China's modernization. In Architectural Notes (pp. 177-186). Shanghai: Tongji Press. 朱亦民 (2018). 后激进时代的建筑笔记 (pp. 177186).上海: 同济大学出版社.

[2] Zou, D. N. (1993) The influence of foreign architecture in China in 1980s four points about the experience of introducing foreign architectural theories. World Architecture(4), (pp54-58). 邹德侬. (1993).八十年代中国的外来建筑影响一一 四谈引进外国建筑理论的经验教训. 世界建筑(4), (pp54-58).

[3] Xue, Q. L.(2006). The Global Impact. Shanghai: Tongji University Press.

[4] Hummelink, M. (2014). The function of special economic zones in the modernization process of china. University of Leiden, Master dissertation.(pp.4)

[5] Data sourced from Statistics Bureau of Shenzhen Municipality website, retrieved 10 January 2019 from http://www.sztj.gov.cn/

[6] Chung, C., Inaba J., Koolhaas, R.\& Leong, S.T. (2001). Great Leap Forward. Cambridge: Harvard Design School. (pp. 123).

[7] Yu, S. S. (2016). Chang'an Avenue and the Modernization of Chinese Architecture. Beijing: SDX Joint Publishing Company.

[8] Xiao, Y. Q. \& Yin, S. (2014). The Architecture in Special Economic Zone: A Review of the Development of Contemporary Architecture in Shenzhen between 
1980s and 1990s. Time+Architecture Journal.(4). 肖毅强, \& 殷实. (2014). “特区建筑” 深圳20世纪80、90年代建筑创作发展评述. 时代建筑(4). (pp18-23).

[9] Zhang, X. (2016). Overview of the development of overseas architectural design practice in Shenzhen. Urbanism and Architecture(21), 199-200. 张晓. (2016). 境外建筑设计在深圳建筑实践的发展概况. 城市建筑(21), 199-200.

[10] Li, Y. (2013). Research on the evolution of foreign design in Shenzhen. Harbin Industrial University, Ph.D. dissertation. 李瑶. (2013). 深圳市境外规划设计实践演进研究. (Doctoral dissertation, 哈尔滨工业大学).

[11] Chen Y.X.(2015). Exploration of Urban Planning: Progress Report of Urban Planning and Implementation for Central Shenzhen (1980-2010). Shenzhen: Haitian Chubanshe

[12] Short, J.R.(2012). Globalization, Modernity and the City. New York: Routledge. (pp. 93)

[13] Wang, W.L. (2007). From the edge to the center: Research on the development of cultural industry in Shenzhen. (pp. 4). Beijing: People's Publishing House. 王为理(2007). 从边缘走向中心: 深圳文化产业发展研究(pp. 4).北京: 人民出版社.

[14] Li, Y.T. (2007). 30th Anniversary of Shennan Road: National Memory on Shennan Road. (pp. 27-29, 44). Shenzhen: Shenzhen Press Group Publishing House. 李咏涛(2009). 大道30: 深南大道上的国家记忆(pp. 2729,44).深圳: 深圳报业集团出版社.

[15] Xiao, Y. Q. \& Yin, S. (2016). A Review of the Development of Contemporary Architecture in Shenzhen between 1980s and 1990s. In Urban Planning, Land \& Resources Commission of Shenzhen Municipality, Time+Architecture Journal. Shenzhen Contemporary Architecture (pp. 84-90). Shanghai: Tongji Press. 肖毅强, 殷实(2016). 深圳20世纪八九十年代建筑创作发展评述. 深圳市规划和国土资源委员会, 《时代建筑》杂志 编著, 深圳当代建筑 (pp. 84-90). 上海: 同济大学出版社.

[16] Meng, J.M. (2006). Shenzhen Architecture for 25 Years. In Zhang, Y.L., Shenzhen Survey and Design for 25 Years: Architectural Design. Beijing: China Architecture \& Building Press. 孟建民(2006). 深圳建筑25年. 张一莉编, 深圳勘察设计 25 年:建筑设计篇. 北京: 中国建筑工业出版社.

[17] Wang, S.N. (2000). Explode the Characteristics of Chinese Architecture between 1990 to 2000. Nanjing: Southeast University, Master Degree dissertation, pp.9. 王韶宁(2000). 20 世纪九十年代中国建筑发展特征初探. 南京: 东南大学. 硕士学位论文, pp.9. 
[18] Chen Y.X. (2015). Shenzhen Futian CBD: A Thirty-year History of Urban Planning and Construction (1980-2010). (pp.100-106). Nanjing: Southeast University Press. 陈一新(2015). 深圳福田中心区(CBD):城市规划建设三十年历史研究.(pp.100106). 南京: 东南大学出版社. 